\title{
Adaptation Study of Relationship Social Comparison Scale
}

\author{
Burak Emre Gürsoy¹, Bengi Öner Özkan ${ }^{2}$
}

Gürsoy, B., E. \& Öner Özkan, B. (2020). Adaptation study of relationship social comparison scale. Nesne, 9(19), 30-41. DOI: 10.7816/nesne-09-19-03

\section{Keywords}

Relationship social

comparison, perceived

relationship quality, adaptation

of relationship social

comparison measure (RSCM),

reliability, convergent validity

\section{Anahtar kelimeler}

İlişkide sosyal karşılaştırma, algılanan ilişki kalitesi, ilişkide sosyal karşılaştırma ölçeğinin (İSKÖ) adaptasyonu, güvenirlik, ayırt edici geçerlik

\begin{abstract}
Current study was aimed to translate Relationship Social Comparison Measure (RSCM) into Turkish and test psychometric properties of the Turkish version. RSCM was originally developed as a one factor scale by LeBeau and Buckingham (2008) in order to assess the frequency of relationship social comparison and circumstances under which comparison occur. However, principal component factor analyses suggested two factor solutions, namely General Tendency $(\alpha=.94)$ and Partner Attributions $(\alpha=.86)$, showing the presence of two constructs tapping different aspects of relationship social comparison. Suggested factor structure of RSCM was also tested with a confirmatory factor analysis, and results supported the two-factor solution (SB $\chi 2(167)=275.13, p=.00, \mathrm{~S}-\mathrm{B} \chi 2 / d f=1.65, \mathrm{CFI}=.95, \mathrm{RMSEA}=.05,90 \%$ CI $[.04, .06])$. The Turkish version of RSCM has high internal reliability as its original form $(\alpha=.94)$. Moreover, the results strongly supported convergent validity with relationship satisfaction, investment, and quality of alternatives. Adaptation of RSCM in Turkish will provide an important tool for studies related to RSC in Turkey with strong psychometric properties. By doing so, it was expected to make scientific contributions to the studies related to romantic relationships in Turkey.
\end{abstract}

\section{İlişki Sosyal Kıyas Ölçeği Adaptasyon Çalışması}

Öz

Bu çalışmada İlişki Sosyal Kıyas Ölçeğinin (İSKÖ) Türkçe 'ye çevrilmesi ve Türkçe versiyonunun psikometrik özelliklerinin test edilmesi amaçlanmıştır. İSKÖ, ilişkilerin sosyal karşılaştırma sıklığını ve karşılaştırmanın gerçekleştiği koşulları değerlendirmek için LeBeau ve Buckingham (2008) tarafından tek faktörlü bir yapıda geliştirilmiştir. Ancak, açımlayıcı faktör analizi, sosyal karşılaştırma kavramının farklı yönlerine değinen iki farklı soru kümesinin olduğunu ve Genel Karşılaştırma Eğilimi $(\alpha=.94)$ ve Partnere Yapılan Atıf ( $\alpha=.86$ ) olmak üzere iki faktörlü çözümün örneklem için uygun olduğunu ortaya koymuştur. Önerilen faktör yapısı doğrulayıcı faktör analizi ile de test edilmiştir ve sonuçlar iki faktörlü çözümü desteklemektedir $(\mathrm{S}-\mathrm{B} \chi 2(167)=275.13, p=.00, \mathrm{~S}-\mathrm{B} \chi 2 / d f=1.65, \mathrm{CFI}=.95, \mathrm{RMSEA}=.05, \% 90 \mathrm{CI}$ $[.04, .06])$. Ölçeğin Türkçe versiyonu orijinal hali gibi yüksek iç tutarlılık katsayısına sahiptir $(\alpha=.94)$. Ayrıca, bulgular Türkçe versiyonun yetişkin bağlanma stili, ilişki tatmini, ilişki yatırımı ve seçeneklerin niteliğinin değerlendirilmesi ile güçlü birleşen geçerliliğine sahip olduğunu göstermiştir. İSKÖ' nün Türkçe 'ye uyarlanması, Türkiye'de romantik ilişkiler ve sosyal karşılaştırmalar ile ilgili akademik yapılacak çalışmalar için güçlü psikometrik özellikleri olan bir araç bir araç sağlayacaktır. Böylelikle Türkiye'de romantik ilişkiler ile ilgili yapılan çalışmalara önemli bilimsel katkılar sağlanması beklenmektedir.

\section{Article History}

Arrived: August 10, 2020

Revised: January 18, 2021

Accepted: February 18, 2021
Author Note: The present research is a part of the Ph.D. thesis conducted by Burak Emre Gürsoy under the supervision of Prof. Dr. Bengi Öner Özkan.

DOI: 10.7816/nesne-09-19-03

${ }^{1}$ Asst. Prof., Istanbul Atlas University, Department of Psychology, gursoyburakemre(at)gmail.com, ORCID: 0000-0001-6813-1996 ${ }^{2}$ Prof., Middle East Technical University, Department of Psychology, bengi(at)metu.edu.tr, ORCID: 0000-0002-9050-2818 
Social Comparison Theory was first demonstrated by Leon Festinger in 1954. According to Festinger (1954), individuals tend to evaluate their abilities and opinions based on those of others similar to them. After Festinger's work in the early 1950s, social comparison theory flourished as a result of other works related to fear and affiliation (Suls \& Wheeler, 2000). During the last 65 years, social comparison theory has evolved, and it is a much more complex theory today (Taylor et al., 2006).

Traditionally, direction of comparison is a fundamental issue within social comparison studies. In 1966, Wheeler described "upward comparison" as a tendency to compare ourselves with those who are better than us due to the interest of self-improvement. Later, Wills (1981) suggested that we are motivated to use "downward comparison", comparing ourselves with those perceived to be inferior, in order to enhance our subjective wellbeing. Although Wills (1981) argued that people are motivated to use downward comparison instead of upward comparison especially under conditions of psychological threat to increase subjective wellbeing and mood, later works suggested that both directions may lead to positive or negative outcomes depending on the context in which the comparison is made. For instance, low self-esteem for cancer patients may lead to negative outcomes resulting from both upward and downward comparisons. It is clear that being diagnosed with cancer and receiving treatment is a unique experience, and that feelings of helplessness or not having control over the situation are more important than the direction of comparison. Similarly, uncertainty and dissatisfaction were also found to lead to negative results for married individuals regardless of the direction of comparison (Buunk et al., 1990).

In addition to direction of comparison, perception of similarity with the comparison target is another important element of social comparison theory. Psychological closeness may lead to assimilation or contrast effect based on perceived similarity with the target (Mussweiler, 2001). As a result of perceived psychological closeness, direction of comparison can lead to positive or negative outcomes and assimilation or contrast effect in different settings (Suls et al., 2002).

\section{Relationship Social Comparison (RSC)}

Intimacy is an important factor in our social life, and it is also found to be important for our physical and mental health (Moss \& Schwebel, 1993). In our search for intimacy, experiencing a romantic involvement has a significant importance. Studies show that almost every one of us experiences romantic relationships at least once in our lives (Madsen \& Collins, 2011). As romantic relationships have been an important aspect in social life, inevitably, social comparison tendencies have found their places in romantic relationships. Even if RSC is a relatively new area in the social comparison field (Wesner, 2008), studies showed that it has been a part of romantic relationships. It seems that people compare themselves with their partners and their relationships with others' romantic involvements. In terms of comparison with a person's own partner, adult attachment style has been shown as a reason for this tendency. Research showed that some people may need to outperform their partners in order to experience closeness due to avoidant attachment orientation (Thai et al., 2015). On the other hand, closeness in romantic relationship works in the opposite way. Higher closeness in romantic relationships can reduce the tendency of upward comparison between dyads by seeing spouse's success as a success for relationships (Lockwood et al., 2004).

In addition to these comparisons within dyads, studies also show that individuals compare their relationships with the relationships of others. Previous studies have reported that RSC between couples are generally used as an evaluation strategy for romantic relationships, and individuals tend to evaluate their own relationships better than others' in terms of satisfaction (Buunk \& Van Der Eijnden, 1997; Buunk \& 
Van Yperen, 1991) Moreover, many individuals believe that their relationships are more equitable (VanYeperen, \& Buunk, 1991) and superior than others' (Rusbult et al., 2000). Also, they believe that their chance of divorce is lesser than others (Weinstein, 1980). Based on these findings, its logical to think that RSC is a tool for some individuals to evaluate their romantic relationship as good as possible. This perceived superiority of one's own relationship seems to be related to positivity bias which leads individuals to have more positive beliefs about their own relationships rather than negative one's (Rusbult et al., 2000).

\section{Relationship Social Comparison, Relationship Quality and Comparison Target}

Relationship quality and comparison target play important role in comparison, and these factors have been widely studied in the field of RSC. Recent evidence suggests that RSC can result in different mood changes based on relationship quality and comparison target in a romantic relationship. For instance, upward RSC can foster relationship satisfaction via inducing hope to become like the target (Morry \& Sucharyna, 2019) or it can decrease relationship satisfaction due to the belief that own relationship is worse than the target (Morry \& Sucharyna, 2016). Moreover, several researchers have also reported that perceived relationship quality in terms of satisfaction and perceived quality of alternative relationships play an important role in tendency to compare our romantic relationship with others'. To illustrate, dissatisfaction in marriages is found to be related to the tendency to talk about marriage with the ones who are believed to have better marriages (Buunk et al., 1991). On the contrary, relationship satisfaction is found to be negatively related to relationship social comparison (White, 2010). Lastly, perceived relationship quality is also found to be associated with RSC interpretations and attention paid to the relationship alternatives (Morry et al., 2018).

Although relationship satisfaction is one of major determinants in RSC, it is not an isolated factor. It has been found to be associated with individual's perception of assimilation to or contrast with the target. It seems that contrast effect is a threat to relationship satisfaction when the comparison target presents high standard for a romantic relationship. On the other hand, assimilation with a high standard target has positive effect on relationship satisfaction. In addition to that, relationship satisfaction also increases, and alternative relationship is perceived less attractive when comparison target contrasted away from ideal relationships (Broemer \& Diehl, 2003). Collectively, these studies outline the critical role of perceived relationship quality and the comparison target in RSC for both upward and downward directions.

\section{Relationship Social Comparison Measure}

To investigate the issues related to our tendency to make RSC as a relationship evaluation strategy, LeBeau and Buckingham (2008) conducted three different studies. They also developed Relationship Social Comparison Measure (RSCM) to study their research interest.

After three consequent studies, they found that RSC tendencies are associated with insecurity, uncertainty, and perceived relationship quality in romantic involvements. To be more specific, results show that anxious and avoidant attachment styles are positively correlated with RSC tendencies. Moreover, lower self-esteem and relationship satisfaction are found to increase the tendency to make RSC. In addition to this, these tendencies also significantly correlate with commitment, investment, and intimacy in romantic involvements. Finally, perceived quality of relationship alternatives is found to be positively related with RSC tendencies (LeBeau \& Buckingham, 2008).

Investigating the tendency to make RSC is a continuing concern within the field of close relationships. Analyzing the effect of these tendencies on romantic involvements is critical to advance the 
knowledge on the relationship between social comparison and relationship evaluations. In addition to this, understanding RSC and its possible associations with close relationships would help practitioners in the field to develop more effective strategies to help couples. The purpose of this study is to translate RSCM into Turkish and test psychometric properties of the Turkish version of RSCM. By doing so, we are expecting to provide a Turkish version of the scale related to RSC tendencies and make contributions to the field.

\section{Method}

\section{Participants}

The sample of the study consists of 251 participants. 180 (78\%) participants were female, and the remaining 71 (\%22) were male. The participants' ages were ranging from 16 to 64, and the mean age was $28.16(S D=6.32)$. The only criterion for participating in this study was being in a romantic involvement. Majority of the sample was labelled as dating, 167, and only 84 participants stated that they were married. 110 participants stated that they were university graduates, 63 participants stated that they were graduated from high school. 61 participants had master's degree, and only 17 participants selected other for their educational status. Relationship satisfaction level of the participants was also recorded in demographic information form with one single 5-point Likert type question. Majority of the sample stated they were satisfied with their relationship, and only 28 participants stated otherwise.

\section{Measurements}

Demographic Information Form: The demographic information of the participants related to their age, sex, socioeconomic status, general satisfaction level within their romantic involvements were collected via this form.

Relationship Social Comparison Measure (RSCM): RSCM was developed by LeBeau and Buckingham (2008) in order to assess the frequency of RSC and circumstances that comparison occur. RSCM is a 5-point Likert-type scale ranging from 1: never to 5: always. RSCM is a one factor scale without any subscales with 24 questions $(\alpha=.92)$. Although LeBeau and Buckingham used RSCM as a one-factor-scale, it seems to have two different sets of questions tapping different aspects of RSC. Some questions were related to general RSC tendencies such as "I compare how happy I am in my relationship to how happy I think others are in their relationships." and "I compare how my partner and I treat each other to how other couples treat each other.". However, some other questions were associated with partner evaluations such as "I compare how supportive my partner is to other peoples' partners." and "I think about how dependable my partner is in comparison to other peoples' partners."

Experiences in Close Relationships Revise (ECR-R): Experiences in Close Relationships Revise (ECR-R) scale was used for assessing the adult attachment orientations. The scale was originally developed by Fraley, Waller, and Brennan (2000) and translated into Turkish by Selçuk, Günaydın, Sümer, and Uysal (2005). Turkish adaptation of ECR-R contains 367 - point Likert type questions ranging from 1: strongly agree to 7 : strongly disagree. ECR-R also has two subcategories to assess different type of attachments, namely anxiety $(\alpha=.86)$ and avoidance $(\alpha=.90)$. Each category has 18 questions. High Internal reliability scores were also found in this study for anxiety $(\alpha=.86)$ and avoidance factors $(\alpha=.86)$.

Relationship Stability Scale (RSS): Relationship Stability Scale (RSS) was originally developed by Rusbult, Martz and Agnew (1998) based on Investment Model Scale in order to analyze the tendency to persist in a relationship. The scale assesses relationship satisfaction, quality of alternatives, investment, and 
commitment. RSS was translated into Turkish by Büyükşahin, Hasta, and Hovardaoğlu (2005). Relationship satisfaction, quality of alternatives, and investment were accepted as the determinants of commitment in romantic relationships (Rusbult et al., 1998); therefore, the scale can be used without commitment subscale as it was in the first adaptation study (Büyükşahin et al., 2005). Parallel to this approach, current study used RSS to assess these determinants as sub groups without commitment subscale. Each three subgroup has 10 questions. First five questions were assessed via 4-point Likert-type scale, while 9-point Likert-type scale was used to assess the last five questions in every subscale. Internal reliability coefficients of relationship satisfaction, quality of alternatives, and investment subscales were $.90, .84$, and .80 respectively in the current study.

\section{Procedure}

Before any translation process began, approval was taken from Human Subject Ethics Committee of Middle East Technical University. Additionally, permission was also granted from the authors of the original scale. After this permission, each item was investigated to clarify the meaning. Based on this investigation, item 15 (I think about how trustworthy my partner is in comparison to other peoples' partners) and item 17 (I think about how dependable my partner is in comparison to other peoples' partners) were found extremely similar when translated into Turkish. Therefore, item 15 was excluded from the scale in order to prevent the risk of asking same question twice. Two different psychologists who have master's degree in the field translated the items into Turkish, resulting in two different versions of scale in the first step. After that, these two versions were checked, and the items revealing similar meaning with the original scale were selected. Then, one bilingual individual translated selected items into English again. Finally, one psychology professor, native in Turkish and uses English as a foreign language, checked and compared the final version of the items with the original form. After this step the translation process was completed. Data was collected via Qualtrics Software within the Middle East Technical University's online data collection system. Moreover, link of the study was also shared via social media to increase diversity in the sample.

\section{Results}

\section{Inter Item Correlations}

Inter item correlation analysis yielded that Turkish version of item 9 (When I am feeling good about my relationship, I compare my relationship with other peoples' relationships) and item 22 (I compare my relationship to other peoples' relationships when I am in a good mood) have high internal correlations ( $r=$ .72). In addition to that, item 23 (I compare my relationship to other peoples' relationships when I am in a bad mood) and item 8 (When I am feeling bad about my relationship, I compare my relationship to other peoples' relationships) also have high correlation scores $(r=.73)$. Due to their high correlation scores with other items, items 9 and 23 were discarded from further analyses.

\section{Exploratory Factor Analysis}

LeBeau and Buckingham (2008) designed RSCM as a single scale without any subscales. However, as mentioned earlier, the scale seems to reveal subscales tapping two different aspects of RSC. In order to make further explanations, a principal component factor analysis with Promax rotation method was conducted in this study via IBM SPSS 23. Initial results showed that the data collected with Turkish RSCM was suitable for exploratory factor analysis $\left[\mathrm{KMO}=.94\right.$; Bartlett $\left.\chi^{2}(253)=3740.90, \mathrm{p}=.001\right]$. Both scree plot and pattern matrix suggested two factor solutions. Based on these results, the first factor was named as General Tendency $(\alpha=.94)$. This factor contains 14 questions and explains $46 \%$ of total variance with 
loadings differing from .48 to .87. Moreover, second factor was named as Partner Attributions $(\alpha=.86)$, and it has 6 questions explaining $11 \%$ of total variance with factor loadings from .51 to .89 (Table 1). Interestingly, one item, item 24 , did not have any significant loadings under both factors.

Table 1

Promax Rotated Factors of Relationship Social Comparison Measure (Turkish)

\begin{tabular}{|c|c|c|}
\hline & $\mathrm{I}$ & II \\
\hline \multicolumn{3}{|l|}{ General Tendency $(\alpha=.93)$} \\
\hline $\begin{array}{l}8 \text { - When I am feeling bad about my relationship, I compare my relationship to other peoples’ relationships. (İlişkim hakkında kötü } \\
\text { hissettiğimde, diğer insanların ilişkileriyle ilişkimi kıyaslarım.) }\end{array}$ & .87 & -.16 \\
\hline $\begin{array}{l}4 \text { - I compare how my partner and I treat each other to how other couples treat each other. (Partnerim/Eşim ile birbirimize nasıl } \\
\text { davrandığımızı başkalarının partnerlerine/eşlerine karşı olan davranışlarıyla karşılaştırırım.) }\end{array}$ & .84 & -.05 \\
\hline $\begin{array}{l}12 \text { - I compare my relationship with other couples whose relationships are better than mine. (İlişkimi, benimkinden daha iyi ilişkisi olan } \\
\text { çiftlerin ilişkileriyle karşlaştırırım.) }\end{array}$ & .83 & -.02 \\
\hline $\begin{array}{l}2 \text { - I pay a lot of attention to how well my partner and I resolve problems compared to how well other couples solve their problems. } \\
\text { (Partnerim/Eşim ile ilişkimizdeki problemleri çözme becerilerimizi, başkalarının ilişkilerindeki problem çözme becerileriyle karşlaştırırım }\end{array}$ & .83 & -.21 \\
\hline $\begin{array}{l}10 \text { - I think about how romantic my relationship is compared to how romantic other couples' relationships are. (Illişkimdeki romantizmi } \\
\text { başkalarının ilişkilerindeki romantizm ile karşılaştırırım.) }\end{array}$ & .82 & -.01 \\
\hline $\begin{array}{l}1 \text { - I compare how happy I am in my relationship to how happy I think others are } \\
\text { in their relationships. (İlişkideki mutluluğumu, başkalarının ilişkilerindeki mutlulukları ile kıyaslarım.) }\end{array}$ & .82 & -.01 \\
\hline $\begin{array}{l}3 \text { - I think about what types of activities my partner and I participate in together compared to what other couples do together. } \\
\text { (Partnerim/Eşim ile birlikte yaptığımız aktiviteleri başkalarının ilişkilerinde yaptıkları aktiviteler ile karşılaştırırım.) }\end{array}$ & .75 & -.01 \\
\hline $\begin{array}{l}14 \text { - I compare the things that my partner does for me to what other peoples' partners do for them. (Partnerimin/Eşimin benim için } \\
\text { yaptıklarını başkalarının partnerleri/eşleri için yaptıklarıyla karşılaştırırım) }\end{array}$ & .71 & .15 \\
\hline $\begin{array}{l}22 \text { - I compare my relationship to other peoples' relationships when I am in a good mood. (Kendimi iyi hissettiğim zamanlarda ilişkimi } \\
\text { başkalarının ilişkileriyle karşılaştırırım) }\end{array}$ & .68 & .09 \\
\hline $\begin{array}{l}7 \text { - I compare how much time my partner and I spend together to how much time other couples spend together. (Partnerim/Eşim ile ne kadar } \\
\text { zaman geçirdiğimizi başkalarının kendi partnerleri/eşleri ile geçirdikleri zamanla karşılaştırırım.) }\end{array}$ & .68 & .12 \\
\hline $\begin{array}{l}11 \text { - I compare my relationship with other couples whose relationships are worse than mine. (İlişkimi, benimkinden daha kötü ilişkisi olan } \\
\text { çiftlerin ilişkileriyle karşılaştırırım.) }\end{array}$ & .67 & .18 \\
\hline $\begin{array}{l}21 \text { - I think about how often my partner and I argue compared to how often other couples argue. (Partnerimle/Eşimle yaşadığımız } \\
\text { tartışmaları başkalarının ilişkilerine kıyasla ne sıklıkta yaşadığımızı düşünürüm.) }\end{array}$ & .66 & .09 \\
\hline $\begin{array}{l}6 \text { - I compare how satisfied I am with my relationship to how satisfied I think others are in their relationships. (İlişkimden ne kadar memnun } \\
\text { olduğumu, başkalarının kendi ilişkilerinden ne kadar memnun olduklarına dair düşüncelerimle karşlaştırırım.) }\end{array}$ & .61 & .21 \\
\hline $\begin{array}{l}12 \text { - I compare my relationship with other couples whose relationships are better than mine. (İlişkimi, benimkinden daha iyi ilişkisi olan } \\
\text { çiftlerin ilişkileriyle karşlaştırırım.) }\end{array}$ & .83 & -.02 \\
\hline \multicolumn{3}{|l|}{ Partner Attribution $(\alpha=.86)$} \\
\hline $\begin{array}{l}20 \text { - I compare how considerate my partner is to how considerate other peoples’ partners are. (Partnerimin/Eşimin diğer insanların } \\
\text { partnerlerine/eşlerine kıyasla ne kadar anlayışlı olduğu üzerine düşünürüm.) }\end{array}$ & -.14 & .89 \\
\hline $\begin{array}{l}18 \text { - I compare how attractive my partner is to how attractive other peoples' partners are. (Partnerimin/Eşimin diğer insanların } \\
\text { partnerlerine/eşlerine kıyasla ne kadar çekici olduğu üzerine düşünürüm) }\end{array}$ & -.13 & .84 \\
\hline $\begin{array}{l}19 \text { - I think about how successful my partner is in comparison to other peoples' partners. (Partnerimin/Eşimin diğer insanların } \\
\text { partnerlerine/eşlerine kıyasla ne kadar başarılı olduğu üzerine düşünürüm. }\end{array}$ & -.08 & .83 \\
\hline $\begin{array}{l}17 \text { - I think about how dependable my partner is in comparison to other peoples’ partners. (Partnerimin/Eşimin diğer insanların } \\
\text { partnerlerine/eşlerine kıyasla ne kadar güvenilir olduğu üzerine düşünürüm.) }\end{array}$ & .01 & .81 \\
\hline $\begin{array}{l}5 \text { - I think about how well my partner and I communicate with each other compared to how well other couples communicate with each } \\
\text { other. (Partnerim/Eşim ile olan iletişimimizin diğer çiftlerin ilişkilerine kıyasla ne kadar iyi olduğu üzerine düşünürüm.) }\end{array}$ & .14 & .64 \\
\hline $\begin{array}{l}13 \text { - I think about how romantic my partner is in comparison to other peoples' partners. (Partnerimin/Eşimin diğer insanların } \\
\text { partnerleriyle/eşleriyle karşılaştırıldığında ne kadar romantik olduğu üzerine düşünürüm.) }\end{array}$ & .18 & .51 \\
\hline $\begin{array}{l}24 \text { - I enjoy listening to other people talk about their relationships. (Diğer insanların ilişkileri hakkında yaptıkları konuşmaları dinlemeyi } \\
\text { severim.) }\end{array}$ & .26 & .27 \\
\hline Explained Total Variance & 45.89 & 11.05 \\
\hline Means & 2.03 & 2.49 \\
\hline Cronbach's Alpha & .94 & .86 \\
\hline
\end{tabular}

Note 1. Numbers in bold in each column represent the factors loadings for each item.

Note 2. Turkish versions of the items can be seen in parenthesis.

\section{Confirmatory Factor Analysis}

Suggested factor structure of RSCM was also tested with a confirmatory factor analysis via EQS software (Bentler, 2006). Based on principal component factor analyses, hypothesized model was created 
and named as Model 1, and it has two factors. First factor was General Tendency with 14 indicator variables, and second factor was Partner Attribution with 6 indicator variables. Analyses were started with Model 1, and two additional models were created based on suggestions of post hoc model modifications.

The results yielded that the data was not normally distributed; thus, robust statistics were chosen for further interpretations (Mardia's $z=13.87$ ). Goodness of fit summary for robust statistics showed that Model 1 did not fit the data (S-B $\chi 2(169)=326.80, p=.000, \mathrm{~S}-\mathrm{B} \chi 2 / d f=1.93$, CFI $=.93$, RMSEA $=.06$, $90 \%$ CI $[.05, .07])$. Loadings of each indicator were significant, and they were falling between 8.56 and 13.27. Correlation between General Tendency and Partner Attribution factors was .58. In order to find a better fitting model, post hoc model modification results were controlled. Post hoc analysis suggested an additional covariance parameter between the error term of item 14 (I compare the things that my partner does for me to what other peoples' partners do for them) and item 16 (I compare how supportive my partner is to other peoples' partners.) as first modification. It seems that concept overlap is responsible for this error covariance. Participants may believe that the things their partners did for them is a part of the support they get from their spouse. Moreover, an additional covariance parameter between the error term of item18 (I compare how attractive my partner is to how attractive other peoples' partners are.) and item 19 (I think about how successful my partner is in comparison to other peoples' partners.) was suggested as second modification. Again, concept overlap can be the reason here, too. Participants can consider attractiveness as a sign of success in social life. Based on these rationales, these two suggestions were added in the model separately. An excel macro designed by Byraynt and Satorra (2013) was used for assessing chi square differences between models. Results yielded significant chi square difference between Model 1 and Model 2 [S-B $\Delta \chi 2(1)=34.95, p=.00]$. Additionally, a significant chi square difference was also found between Model 2 and Model 3 [S-B $\Delta \chi 2(1)=85, p=.00]$. Finally Model 3 (Figure 1) provided a good fit with the data $(\mathrm{S}-\mathrm{B} \chi 2(167)=275.13, p=.00, \mathrm{~S}-\mathrm{B} \chi 2 / d f=1.65, \mathrm{CFI}=.95, \mathrm{RMSEA}=.05,90 \%$ CI $[.04, .06])$. Fit indices for each model can be seen in Table 2 .

Table 2

Model Fit Indices for Study Models

\begin{tabular}{lccccccccc}
\hline & $S-B \chi 2$ & $d f$ & $S-B \chi 2 / d f$ & CFI & $\% 90$ CI & RMSEA & SRMR & $p$ \\
\hline MODEL 1 & 326.80 & 169 & 1.93 & .93 & $.05-.07$ & .06 & .07 & .000 \\
MODEL 2 & 291.93 & 168 & 1.73 & .94 & $.04-.06$ & .05 & .06 & .000 \\
MODEL 3 & 275.13 & 167 & 1.65 & .95 & $.04-.06$ & .05 & .06 & .000 \\
\hline
\end{tabular}

Note 1. Model 1: The first model without any modification.

Note 2. Model 2: Second model after an additional covariance parameter between the error term of item 14 and item 16

Note 3. Model 3: Third model after an additional covariance parameter between the error term of item18 and item 19

\section{Convergent Validity}

Current study analyzed the relationship between RSCM, adult attachment orientation, and relationship satisfaction in order to investigate convergent validity of RSCM. In this study, adult attachment orientation was measured via ECR-R (Selçuk et al., 2005), and results were in the expected direction (Table $3)$. According to results, RSC tendency was positively correlated with anxious $(r=.40)$ and avoidant $(r=$ .18) attachment orientations, and investment in romantic relationships $(r=.25)$. In other words, individuals with anxious or avoidant form of attachment have higher tendency to make RSC, and investments also increase RSC tendencies. Moreover, relationship satisfaction, measured via RSS (Büyükşahin et al., 2005), was also found to be negatively correlated with RSC tendency $(r=-.21)$. It seems that the more an individual is satisfied with their relationship, the less they tend to make comparison. Both results were found to be in 
the expected direction as the original work of LeBeau and Buckingham (2008). Interestingly, quality of alternatives did not yield significant correlations with RSC tendencies $(r=.08)$.

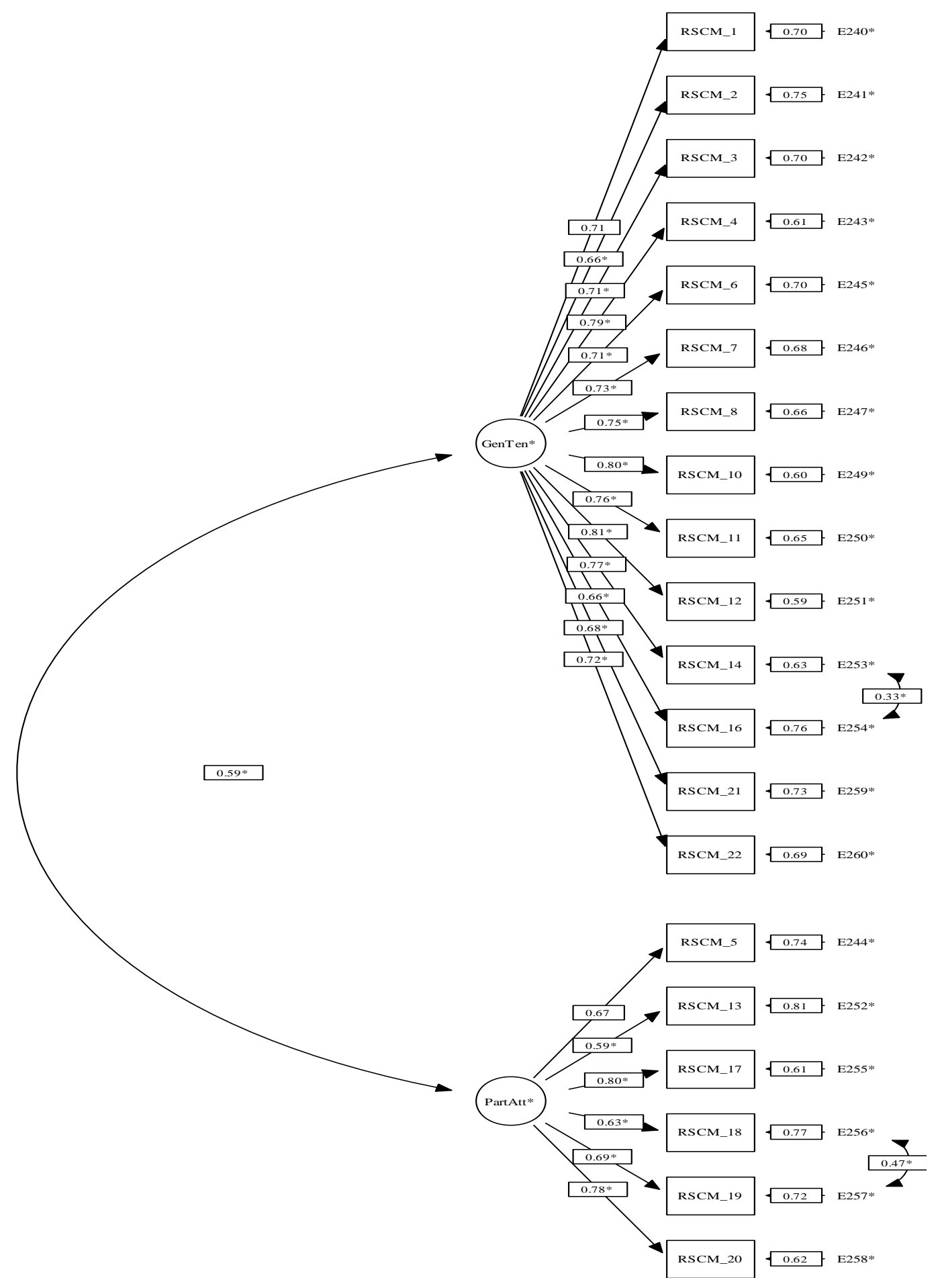

Figure 1. Final Model for RSCM 
Table 3

Item Correlations between RSCM and other Variables

\begin{tabular}{|c|c|c|c|c|c|c|c|c|}
\hline & 1 & 2 & 3 & 4 & 5 & 6 & 7 & 8 \\
\hline 1. RSCM Total & & & & & & & & \\
\hline 2. RSCM GT & $.95 * *$ & & & & & & & \\
\hline 3. RSCM PA & $.79 * *$ & $.55 * *$ & & & & & & \\
\hline 4. Anxious & $.40 * *$ & $.46 * *$ & $.15^{*}$ & & & & & \\
\hline 5. Avoidant & $.18 * *$ & $.26 * *$ & -.03 & $.46 * *$ & & & & \\
\hline 6. Investment & $.25 * *$ & $.26 * *$ & $.15^{*}$ & $.24 * *$ & -.06 & & & \\
\hline 7. Satisfaction & $-.21 * *$ & $-.32 * *$ & .08 & $-.31 * *$ & $-.40 * *$ & $.18 * *$ & & \\
\hline 8. Quality of Alternatives & .08 & $.15^{* *}$ & -.06 & .10 & .12 & -.12 & $-.38 * *$ & \\
\hline Means & 2.17 & 2.03 & 2.49 & 3.36 & 2.48 & 4.28 & 7.24 & 4.50 \\
\hline SD & .74 & .78 & .95 & .98 & 98 & 2.03 & 1.51 & 1.99 \\
\hline
\end{tabular}

\section{Reliability Analyses}

The Turkish version of RSCM has high internal reliability as its original form ( $\alpha=.94)$. In addition to that, two-factor structure has also high internal reliability for two factors, namely General Tendency $(\alpha=.94)$ and Partner Attributions $(\alpha=.86)$. Guttman split half coefficient was .85 for the whole scale, .91 for General Tendency factor and .82 for Partner Attributions factor. None of the items will increase internal consistency significantly if deleted.

\section{Discussion}

According to Festinger (1954), individuals have a tendency to evaluate their abilities and opinions based on abilities and opinions of similar others. Similar evaluation strategy can also be used in romantic relationships. According to studies, individuals evaluate their relationships better than others' in terms of satisfaction (Buunk \& VanYeperen, 1991; Buunk \& Van Der Eijnden, 1997), equitability (VanYeperen, \& Buunk, 1991), and superiority (Rusbult et al., 2000). Moreover, they also believe that their chance of divorce is lesser than others (Weinstein, 1980). As Van Lange and Rusbult (1995) have found, individuals have more positive beliefs about their own relationships rather than negative ones. In addition to these findings, assessing individuals' tendency to make RSC is also an important concern for the field of RSC. To address the frequency of RSC and circumstances that comparison occur, LeBeau and Buckingham (2008) developed RSCM. The purpose of this study is to translate RSCM into Turkish and test psychometric properties of Turkish version of RSCM.

Translation back translation method was used for translating the items of the original scale. By doing so, current study was able to provide the best possible meanings for each item. Psychometric properties of the scale showed that the Turkish adaptation of RSCM has high internal consistency as its original form. In order to investigate convergent validity, relationship satisfaction, investment, quality of alternatives, and adult attachment orientation were also measured. According to the results, the translated scale was positively correlated with anxious and avoidant attachment styles and investment; and negatively with satisfaction. These findings are similar with the findings of LeBeau and Buckingham (2008) and provide evidence for convergent validity of the adapted RSCM. However, on the contrary to the expectations, quality of alternatives did not yield any significant correlation with RSC tendencies. One possible explanation related 
to this finding can be related to participants' high relationship satisfaction. Almost $89 \%$ of the participants stated that they were satisfied with their relationships in demographic information form. This high percentage of satisfaction may work as a protective mechanism against RSC. Thus, quality of alternatives may have no significant effect on RSC tendencies in this study. In addition to that, due to this high perceived relationship satisfaction, participants may have wished avoid experiencing cognitive dissonance resulting from giving attention to other possible options in their ongoing relationships. Furthermore, one study conducted by Okutan and Büyükşahin-Sunal (2010) found that tendency to assess the quality of alternatives was higher in male participants in comparison to females. Similar result was also found in the original work of Rusbult, Martz, and Agnew (1998). From this point of view, high number of female participants in this study can be seen as an explanation related to this finding.

Initial principal component analysis suggested two factor solution. It seems that Turkish adaptation of RSCM has two sub scales unlike the original scale. Based on these results, these two factors were named as General Tendency and Partner Attribution. Both sub scales have high internal consistency. In order to make further explanations, current study used a confirmatory factor analysis. Based on the suggestions from the relevant literature (Byrne, 2013; Hu \& Bentler, 1999), results yielded a good model fit after two modifications. It seems that different aspects of RSC were addressed in the original scale, which yielded two different sub-categories in turn. However, due to the high internal reliability scores of subscales, we believe that Turkish version of RSCM can be used as one single scale, as well. Based on the research purpose, two factor solution can also be preferred in order to assess different dimensions of RSC tendencies.

Several limitations of this study need to be acknowledged. Firstly, majority of the participants of the study were female. This inequality between female and male participants may have caused the study to fall short in finding some important significant correlations. Secondly, self-report measure was used to gather data, and some variables were open to social desirability bias. To illustrate, study tried to assess relationship satisfaction extrinsically; however, it must be noted that it can be hard to state dissatisfaction about ongoing relationships extrinsically. Future studies can prefer evenly distributed participant numbers based on gender and use implicit association techniques for assessment to avoid social desirability.

All the things considered, we believe that this Turkish adaptation of RSCM has strong psychometric properties in terms of reliability and convergent validity. We are hoping that this adaption of RSCM will provide an important tool for studies related to RSC in Turkey. Practitioners in the field can also benefit from these studies about the possible effects of RSC on romantic involvements and its association with other possible factors related to close relationships to develop more effective strategies to help couples.

\section{References}

Bentler, P. M. (2006). EQS 6 structural equations program manual. In Los Angeles: BMDP Statistic Software.

Bryant, F. B., \& Satorra, A. (2013). EXCEL macro file for conducting scaled difference chi-square tests via LISREL 8, LISREL 9, EQS, and Mplus. Available from the authors

Broemer, P., \& Diehl, M. (2003). What You Think Is What You Get: Comparative Evaluations of Close Relationships. Personality and Social Psychology Bulletin. https://doi.org/10.1177/0146167203256918

Buunk, B. M. P., Vanyperen, N. W., Taylor, S. E., \& Collins, R. L. (1991). Social comparison and the drive upward revisited: Affiliation as a response to marital stress. European Journal of Social Psychology. https://doi.org/10.1002/ejsp.2420210607 
Buunk, B. P., Collins, R. L., Taylor, S. E., VanYperen, N. W., \& Dakof, G. A. (1990). The Affective Consequences of Social Comparison: Either Direction Has Its Ups and Downs. Journal of Personality and Social Psychology. https://doi.org/10.1037/0022-3514.59.6.1238

Buunk, B. P., \& Van Der Eijnden, R. J. J. M. (1997). Perceived prevalence, perceived superiority, and relationship satisfaction: Most relationships are good, but ours is the best. Personality and Social Psychology Bulletin. https://doi.org/10.1177/0146167297233001

Buunk, B. P., \& Van Yperen, N. W. (1991). Referential Comparisons, Relational Comparisons, and Exchange Orientation: Their Relation to Marital Satisfaction. Personality and Social Psychology Bulletin. https://doi.org/10.1177/0146167291176015

Büyükşahin, A., Hasta, D., \& Hovardaoğlu, S. (2005). İlişki istikrarı Ölçeği: Geçerlik ve Güvenirlik Çalışması. Türk Psikoloji Yazıları, 8(16), 25-35.

Byrne, B. M. (2013). Structural equation modeling with EQS: Basic concepts, applications, and programming, second edition. In Structural Equation Modeling with EQS: Basic Concepts, Applications, and Programming, Second Edition. https://doi.org/10.4324/9780203726532

Festinger, L. (1954). A Theory of Social Comparison Processes. Human Relations, 7(2), 117-140. https://doi.org/10.1177/001872675400700202

Fraley, R. C., Waller, N. G., \& Brennan, K. A. (2000). An item response theory analysis of self-report measures of adult attachment. Journal of Personality and Social Psychology. https://doi.org/10.1037/0022-3514.78.2.350

Hu, L. T., \& Bentler, P. M. (1999). Cutoff criteria for fit indexes in covariance structure analysis: Conventional criteria versus new alternatives. Structural Equation Modeling. https://doi.org/10.1080/10705519909540118

IBM, Corporation, I. B. M., SPSS, IBM, Statistics, I. B. M. S., IBM, Statistics, I. B. M. S., IBM, SPSS/IBM, IBM Corp., IBM, Statistics, I. B. M. S., IBM, Germany, T., Statistics, I. B. M. S., IBM, Statistics, I. B. M. S., IBM, SPSS/IBM, ... SPSS/IBM. (2016). IBM SPSS Statistics 23. Release Notes. https://doi.org/10.1080/02331889108802322

LeBeau, L. S., \& Buckingham, J. T. (2008). Relationship social comparison tendencies, insecurity, and perceived relationship quality. Journal of Social and Personal Relationships, 25(1), 71-86. https://doi.org/10.1177/0265407507086806

Lockwood, P., Dolderman, D., Sadler, P., \& Gerchak, E. (2004). Feeling better about doing worse: Social comparisons within romantic relationships. Journal of Personality and Social Psychology, 87(1), 80 95. https://doi.org/10.1037/0022-3514.87.1.80

Madsen, S. D., \& Collins, W. A. (2011). The Salience of Adolescent Romantic Experiences for Romantic Relationship Qualities in Young Adulthood. Journal of Research on Adolescence, 21(4), 789-801. https://doi.org/10.1111/j.1532-7795.2011.00737.x

Morry, M. M., \& Sucharyna, T. A. (2016). Relationship social comparison interpretations and dating relationship quality, behaviors, and mood. Personal Relationships, 23(3), 554-576. https://doi.org/10.1111/pere.12143

Morry, M. M., \& Sucharyna, T. A. (2019). Relationship social comparisons in dating and marital relationships: Adding relationship social comparison interpretations. Journal of Social Psychology, 159(4), 398-416. https://doi.org/10.1080/00224545.2018.1498826

Morry, M. M., Sucharyna, T. A., \& Petty, S. K. (2018). Relationship social comparisons: Your facebook page affects my relationship and personal well-being. Computers in Human Behavior, 83, 140-167. https://doi.org/10.1016/j.chb.2018.01.038

Moss, B. F., \& Schwebel, A. I. (1993). Defining Intimacy in Romantic Relationships. Family Relations. https://doi.org/10.2307/584918 
Mussweiler, T. (2001). "Seek and ye shall find": Antecedents of assimilation and contrast in social comparison. European Journal of Social Psychology, 31(5), 499-509. https://doi.org/10.1002/ejsp.75

Okutan, N., \& Büyükşahin-Sunal, A. (2010). Romantik ilişkilerde bağlanım: Dindarlık algısı ve romantik ilişkilerle ilgili kalıpyargılar. Türk Psikoloji Yazilari.

Rusbult, C. E., Martz, J. M., \& Agnew, C. R. (1998). The Investment Model Scale: Measuring commitment level, satisfaction level, quality of alternatives, and investment size. Personal Relationships. https://doi.org/10.1111/j.1475-6811.1998.tb00177.x

Rusbult, C. E., Van Lange, P. A. M., Wildschut, T., Yovetich, N. A., \& Verette, J. (2000). Perceived superiority in close relationships: Why it exists and persists. Journal of Personality and Social Psychology. https://doi.org/10.1037/0022-3514.79.4.521

Selçuk, E., Günaydın, G., Sümer, N., Uysal, A. (2005). Yetişkin bağlanma boyutları için yeni bir ölçüm: Yakın ilişkilerde yaşantılar envanteri-II'nin Türk örnekleminde psikometrik açıdan değerlendirilmesi. Türk Psikoloji Yazıları.

Suls, Jerry; Wheeler, L. (2000). Handbook of Social Comparison.

Suls, J., Martin, R., \& Wheeler, L. (2002). Social comparison: Why, with whom, and with what effect? Current Directions in Psychological Science, 11(5), 159-163. https://doi.org/10.1111/14678721.00191

Taylor, S. E., Peplau, L. A., \& Sears, D. (2006). Social Psychology (12th ed.), (pp. 132-168.) Upper Saddle River, N.J: Pearson/Prentice Hall.

Thai, S., Lockwood, P., Pinkus, R. T., \& Chen, S. Y. (2015). Being better than you is better for us: Attachment avoidance and social comparisons within romantic relationships. Journal of Social and Personal Relationships. https://doi.org/10.1177/0265407515578826

Van Lange, P. A. M., \& Rusbult, C. E. (1995). My Relationship is Better than- and Not as Bad as--Yours is: The Perception of Superiority in Close Relationships. Personality and Social Psychology Bulletin. https://doi.org/10.1177/0146167295211005

Vanyperen, N. W., \& Buunk, B. P. (1991). Sex-Role Attitudes, Social Comparison, and Satisfaction with Relationships. Social Psychology Quarterly, 54(2), 169. https://doi.org/10.2307/2786934

Weinstein, N. D. (1980). Unrealistic optimism about future life events. Journal of Personality and Social Psychology, 39(5), 806-820. https://doi.org/10.1037//0022-3514.39.5.806

Wesner, K. (2008). Social comparison of romantic relationships: The influence of family, friends, and media.

$\mathrm{http} / /$ books.google.com/books?hl=en\&lr=\&id=DdGgaAU55TkC\&oi=fnd\&pg=PR3\&dq=Social+comp arison+of+romantic+relationships+:+The+influence+of+family+,+friends+,+and+media+by\&ots=Exp OHE3Anb\&sig=JpabdXhmoQ9LF25IMqv4YxcXf18

Wheeler, L. (1966). Motivation as a determinant of upward comparison. Journal of Experimental Social Psychology. https://doi.org/10.1016/0022-1031(66)90062-X

White, G. A. (2011). Implications of relationship social comparison tendencies among dating and married individuals. Dissertation Abstracts International, B: Sciences and Engineering.

Wills, T. A. (1981). Downward comparison principles in social psychology. Psychological Bulletin. https://doi.org/10.1037/0033-2909.90.2.245 